\title{
Revenue Diversification, Risk and Bank Performance of Vietnamese Commercial Banks
}

\author{
Khanh Ngoc Nguyen \\ Faculty of Banking, Banking Academy, Hanoi 100000, Vietnam; khanhnguyensaxion@gmail.com
}

Received: 28 June 2019; Accepted: 26 August 2019; Published: 28 August 2019

\begin{abstract}
In the future, when the process of economic integration in the banking sector is more powerful, and competitive, diversifying revenue is an inevitable and objective trend to help the banks increase profits, minimize risks and improve their competitive position in the system. The research is on the relationship between revenue diversification, risk and bank performance using data from audited financial statements and annual reports of 26 commercial banks listed and unlisted in Vietnam during the period 2010-2018. The research method uses Generalized Method of Moment (GMM) modeling techniques to solve endogenous problems, variance and autocorrelation in the research model. Research results show that diversification negatively impacts profitability and the higher the diversification, the higher the risk of commercial banks. However, the more diversified listed banks, the more increased the bank's stability. The banks show the weakness and lack of experience of the banking system in developing a reasonable profit transformation model. The revenue diversification of banks is currently passive and moves slowly. Interest income is still the motivation of bank development, boosting profit growth. Growth, as well as the contribution from service activities, is not commensurate with potentials; although there are many positive points, they are not enough to cover risks from net interest income activities.
\end{abstract}

Keywords: revenue diversification; bank risks; bank performance; net interest income; non-interest income

\section{Introduction}

In recent times, the Vietnamese banking system has changed significantly. Some banks have merged and foreign banks have been allowed to participate in the banking sector. Great and healthy banks are strongly encouraged to seek the consolidation and development of universal banking services to become essential in the banking sector. The merger or consolidation of banks has created a new wave of competitive pressure and contributed to restructuring the banking sector. From specialized credit operations, banks have begun to change by switching to non-traditional activities to diversify revenues, minimize risks as well as seek new opportunities for themselves. Business strategies of banks are reflecting a continuously great change in income structure. Interest income is still the dominant revenue source in the income structure of the industry; however, it has been on a downward trend in recent years. Non-interest income has increased from 18\% in 2015 to $23 \%$ at the end of 2017. However, this is still a relatively low number compared to other countries in the region such as the Philippines, Myanmar and Singapore, whose non-interest income rate is up to 35-40\% (Source: World Bank (2018)). This shows that non-traditional activity is still a potential activity for commercial banks in Vietnam. In the future, when the process of economic integration in the banking sector is more powerful, the banking system will become more competitive; thus, diversifying revenue is an inevitable and objective trend that will help the banks increase profits, minimize risks and improve their competitive position in the system. 
The bank performance in research documents is often used as an economic performance, which refers to a bank's ability to minimize costs (cost savings) or maximize profits (profit efficiency). Some recent research highlights the importance of bank diversification. The traditional view in the banking sector is that revenue from non-interest activities is more stable than interest income; thus, the bank's risk will be reduced when diversification (Berger 1995; Elsas et al. 2010), Laeven and Levine (2007) and (Stiroh and Rumble 2006) argued that non-interest income contributed to profit growth and lowered risks. Boot and Schmeits (2000); Elsas et al. (2010) showed that by diversifying income, products or different markets, banks could reduce the risk of bankruptcy due to different business activities related to different risk levels. Similarly, Sanya and Wolfe (2011) showed that diversification helped banks increase profits and reduce risks. Rossi et al. (2009); and Lee et al. (2014) argued that bank risks were reduced through the revenue diversification and increase of bank performance.

However, there are many researches that does not support the banks' diversification strategy. Some argue that the high cost of diversification increases risks and reduces profits when the banks perform encroaching on their amateur activities, or that the diversification will cause adverse impacts on the bank performance due to managing many operational areas. (Gamra and Plihon 2011; Stiroh and Rumble 2006) also showed that the greater reliance on non-interest income has led to higher volatility in bank income and higher risks but not higher returns. The bank's expansion of non-interest income means increasing fixed costs, leading to increased leverage in banking operations and higher risks (De Jonghe 2010; Fiordelisi et al. 2011). This argument is supported by experimental studies such as Lepetit et al. (2008) and Baele et al. (2007). The above studies show that diversification owns both advantages and disadvantages. However, whether banks have diversified or not, diversification has been going on because of its necessity for the purpose of seeking profits as well as enhancing the competitiveness of the banks in the context of international economic integration. All these reforms aim to modernize the banking activities and to improve the financial service products. In this paper, the author analyzed the main factors that determine the level of non-interest income for Vietnamese banks, then, the author studied the impact of non-interest income on the banking profitability, and finally, the association between non-interest income and the level of risk taking was explored. To the best of the author's knowledge, there has not been any study that has analyzed the impact of diversification on bank performance and risk within the Vietnam context. Therefore, this paper tries to fill the gap in the literature by providing a comprehensive study.

\section{Theoretical Background and Literature Review}

Studies of diversification between banks in the US and Europe, in general, showed that it was related to non-interest income structure of commercial banks. Revenue diversification has a negative impact on the profit risk of US banks (DeYoung and Roland 2001; Stiroh 2004a). However, the diversification enhanced the level of profit risk of European banks (Baele et al. 2007; Chiorazzo et al. 2008). DeYoung and Rice (2004) analyzed the impact of non-interest income on the profits and risks of US banks and showed that despite income diversification boosted profitability, a banking diversification strategy increased the fluctuation of income. Acharya et al. (2006) carried out research on 105 banks in Italy during the period 1993-1999, and concluded that diversification did not guarantee superior performance and or reduce risks for banks. In particular, for high-risk banks, diversification reduced profits and created more risky loans; for low-risk banks, diversification created an ineffective balance between profits and risks. Laeven and Levine (2007) conducted banking research of 13 Western European countries and concluded that revenue diversification had two negative impacts on risks. Baele et al. (2007) studied the effects of revenue diversification on bank performance and risks. Research data were tabular data from banks from 17 European countries in the period 1989-2004. Research results showed that banks with a higher non-interest income ratio of total revenue had a better bank performance. In addition, diversifying revenues from different activities will increase the risks of the banking system. Rossi et al. (2009) showed that diversification increased profitability and reduced bank risks. Elsas et al. (2010) studied the impact of diversification 
on bank business performance, using developed countries' data, namely, Australia, Canada, France, Germany, Italy, United Kingdom, United States, Spain and Switzerland, during the period 1996-2008. The results demonstrated that revenue diversification improved bank profitability even during the 2007-2008 financial crisis. Sanya and Wolfe (2011) studied the impact of risk diversification and bank performance in 11 emerging economies, concluding that revenue diversification reduced bankruptcy risk and increased profits for banks.

DeYoung and Torna (2013) analyzed the impact of revenue diversification on the failure of banks during the financial crisis. The research showed that switching to non-traditional banking activities had a significant impact on the bank's ability to fail in the crisis, depending on the bank's financial condition. While banks are more involved in non-traditional activities, it will reduce the risk of failure of credit institutions; the banks with financial degradation when participating in these activities will increase their probability of failure. Delpachitra and Lester (2013) used panel data of 09 listed by Australian banks in the period 2000-2009 to study the impact of the diversification of banking activities. Experimental results showed that revenue and diversification of non-interest income reduced profitability and did not improve the bank's default risk. Research results show that non-interest income activities will not benefit the bank. Meanwhile, Williams and Prather (2010) focused on the impact of non-interest income on the bank's profitability risk. As a result, non-interest income was riskier than profit income but brought diversified benefits to bank shareholders. (Li and Zhang 2013) studied the increasing dependence on the non-interest income of Chinese banks in the period 1986-2008. Research results showed that diversification of non-interest income brought benefits for banks, but also increased risks to the system.

Meslier et al. (2014) used panel data of 39 global and commercial banks in the Philippines during the period 1999-2005 to study the role and value of bank diversification. Research results indicated that non-interest income increased bank profits and regulated bank risks. In the same view, Lee et al. (2014) studied the impact of non-interest income on bank profits and risks, using bank data of 22 countries in Asia with 967 private banks in the period 1995-2009. By implementing the GMM regression method, the results showed that non-credit activities of Asian banks' minimized risks, but did not increase profitability. Brighi et al. (2014) used panel data of 52 Corporate Organization Banks (BHCs) in Italy in the period of 2006-2011 to test the impact of revenue diversification on bank performance. Unlike studies on diversification that focused on its impact on equity and debt value and portfolio strategy of profitability, risk and scientists conducted other ways to test the impact of non-interest business activities on the bank's performance. Diversification increased bank profits on the basis of risk adjustment.

\section{Data and Methodology}

\subsection{Data Collection}

The data used in the study were collected from the audited financial statements and annual reports of 26 commercial banks, including 12 listed banks and 14 unlisted banks in Vietnam in the period of 2010-2018. After that, the researcher selected banks owning full financial statements, including balance sheet, income statement, cash flow statement and notes to financial statements. In addition, data were also collected from the website http://finance.vietstock.vn, from the State Bank of Vietnam, websites of commercial banks under study, General Statistics Office of Vietnam, Ministry of Finance. After collection, the data were imported into an Excel file and edited and encoded in this file. The next step is to conduct data cleaning to detect errors; empty cells that lack information, wrong information and complete the data matrix. Then, the researcher used Stata 13 software to calculate and process data according to the model. 


\subsection{Data Analysis}

This study applied a dynamic panel data approach proposed by Arellano and Bover (1995); Blundell and Bond (2000) used GMM modeling techniques to solve endogenous problems, variance and autocorrelation. With the foundation of theoretical studies and empirical studies, like Stiroh (2004a); Mercieca et al. (2007); Lepetit et al. (2008); Chiorazzo et al. (2008); Lee et al. (2014); Geambasu et al. (2013) the study to determine the following basic models:

$$
\begin{gathered}
\text { Performance }(\mathrm{ROA}, \mathrm{ROE})_{i, t}=\alpha_{i, t}+\beta_{1} \mathrm{INT}_{i, t}+\beta_{2} \mathrm{HHI}_{i, t}+\sum_{s=3}^{8} \beta_{s} \lambda_{i, t}+\varepsilon_{i, t} \\
\text { Bank Risk }(\mathrm{Z}-\text { score })_{i, t}=\alpha_{i, t}+\beta_{1} \mathrm{INT}_{i, t}+\beta_{2} \mathrm{HHI}_{i, t}+\sum_{s=3}^{8} \beta_{s} \lambda_{i, t}+\varepsilon_{i, t}
\end{gathered}
$$

In which $i$ represents the number of banks in the research sample, $i=1 \ldots 28 ; t$ represents the time $(t=2010-2018), \beta$ represents the regression coefficient $\lambda$ which is the control variable matrix, $\varepsilon$ which is the error. Measuring efficiency by ROA, ROE; INT represents the ratio of net interest income, HHI represents the revenue diversification variable. Control variables include: natural logarithm of total assets; loan outstanding balance/asset ratio; equity/asset ratio; non-performing loan/loan outstanding balance ratio; asset growth; liquidity ratio (see Table 1).

- Bank performance (ROA, ROE)

Bank performance from the point of view of shareholders of a bank is obtaining profit by maximizing the revenue and minimizing the costs. Economic theories show that, in the situation of perfect competition, profit maximization is equal to minimizing costs. In practice, however, it can interfere factors such as changes in the regulatory framework that would disturb obtain desired performance. The factors that could explain the deviation from profit maximization can be grouped into two categories: incorrect incentives and inefficiency (Bikker and Bos 2008). Bank's economic efficiency was measured by comparing its performance to that of the best-practice bank. Economic efficiency, as defined by Aigner et al. (1977), refers to a bank's ability to minimize its cost or maximize its profit. Similarly, profit efficiency is determined by comparing its profit to what the best-practice bank would produce given the same bundle of inputs Berger and Mester (1997). All performance measures, regardless of their specific objectives, use accounting and market data to assess the financial condition of an institution at a point in time, as well as to determine how well it has been managed over a period of time (Jianu et al. 2017). Profitability can be used as a summary index of performance (De Andres and Vallelado 2008; Liang et al. 2013). There are two methods commonly used to measure the performance of businesses in general and banks in particular, including returns on assets (ROA), defined as the return on the average total assets. ROE is defined as the ratio of returns on equity. Measure of bank performance differs from that of Laeven and Levine (2007), who used Tobin's Q (i.e., the sum of the market value of common equity plus the book value of preferred shares divided by the book value of total assets). Given the limited data on the market value of banks, this study uses ROA to measure bank performance and to derive excess value. Bank performance measures should be limited to ROA or ROE and should not cover other measures such as cost efficiency and asset quality cost to income ratio (CTI, an inverse proxy for bank (cost) efficiency), and loan loss reserves divided by gross loans (LLR, an inverse proxy for asset quality or bank stability) (Beck et al. 2013; Vennet 2002). In banking activities, increasing profits means banks face more and more risks. Therefore, in addition to the goal of increasing profits, banks need to diversify to spread risks (Chiorazzo et al. 2008; Stiroh 2004a, 2004b).

- Revenue diversification (HHI)

The degree of banking diversification is measured by the ratio of net interest income and non-interest income (Lepetit et al. 2008; Stiroh 2004a, 2004b). Mercieca et al. (2007) conducted the 
measurement of diversification by building Herfindahl-Hirschman Index (HHI) for each bank. This method measures the ratio between diversification and the main business activities of the bank. HHI (Rev) will be calculated by the following formula:

$$
\mathrm{HHI}_{\mathrm{Rev}}=\left(\frac{\mathrm{NON}}{\mathrm{NETOP}}\right)^{2}+\left(\frac{\mathrm{NET}}{\mathrm{NETOP}}\right)^{2}
$$

In which, NETOP $=$ NON + NET; NON represents non-interest income, NET represents net interest income. This formula indicates that if the bank focuses on increasing profits, its diversification will be decreased. Stiroh and Rumble (2006) clearly saw that revenue diversification was offset by the increase in non-interest activity; however, it also increased banks' risk. Demirgüç-Kunt and Huizinga (2010) also claimed that higher degrees of increased non-interest income led to higher risks for banks.

- Bank risk (Z-score)

As previously stated, we proxy bank risk using two complementary metrics that are intuitive and easily measured: the NPL (Non-Performing Loan) and the Z-score (Demirgüç-Kunt and Huizinga 2010; Köhler 2015; Laeven and Levine 2009). Z-score is an inverse proxy for a firm's probability of failure (insolvency risk), combining profitability, leverage, and return volatility into a single measure. A higher Z-score indicates higher bank stability and less overall bank risk (Hsieh et al. 2013; Kick and von Westernhagen 2009). The Z-score is considered a better measure of bank risk than the NPL, because non-performing loans are traditionally backward looking and highly procyclical (Bikker and Metzemakers 2005; Laeven and Majnoni 2003). This is a criticism that does not concern the Z-score as much because changes in bank riskiness are captured through the variance component of this index (Delis et al. 2011). In addition, the Z-score represents a more universal measure of bank risk that captures more than credit risk alone (Agoraki et al. 2011). Risk measurement method is formed based on the theoretical background of bankruptcy risk measurement of Roy (1952); Boyd and Runkle (1993) and Lepetit and Strobel (2015) and the theory of bank diversification of Mercieca et al. (2007); Chiorazzo et al. (2008) and Lee et al. (2014). Until now, Roy's Z-score (1952) is considered an index of bank's bankruptcy prediction which is widely used in previous studies. Higher Z-Score index indicates lower possibility of bankruptcy (Lepetit and Strobel 2015). It will be calculated by the following formula:

$$
\mathrm{Z}-\text { score }=\frac{\mathrm{ROA}+\mathrm{ETA}}{\mathrm{SDROA}}
$$

\section{- Bank size (SIZE)}

According to Demsetz and Strahan (1997), diversification has a positive relationship with the size of bank assets, the larger the size of bank deposits, the higher the loan balance for customers. Bank size is measured by logarithms by total assets. Curi et al. (2015) and Berger et al. (2010) argued that there was a nonlinear relationship between size and business performance. The effect of bank size on performance is still controversial. McAllister and McManus (1993) argued that large banks often had the advantage of size and had more opportunities to diversify risks than small banks. Therefore, large banks will have lower costs and higher profits (Goddard et al. 2004). On the other hand, Vallascas and Keasey (2012) argued that large banks were more motivated to make more risky investments. Therefore, large banks may be less effective than small banks.

- Gross interest revenue (INT)

INT is often used to express the impact of interest rate risk on the possibility of bankruptcy of commercial banks because interest income is the main source of income. The ratio increases due to an increase in interest income or a decrease in total assets. This shows that the bank is at high risk when net interest income is reduced or investment and lending on risky accounts. According to Halling and Hayden (2006), INT has a contravariant relationship with Z-score. 
- Capitalization ratio, measured as the ratio of equity to total assets (ETA)

This variable shows the level of financial leverage of a bank. High leverage ratio means high risk. This variable is also used in most recent studies such as Sanya and Wolfe (2011); Chiorazzo et al. (2008) and (Stiroh 2004b). High-capitalized banks are less risky and so generate lower profits (Hughes and Mester 1998). The contrary relationship between capital and profits emphasizes that higher insurance costs can prevent bankruptcy risks with low capital asset ratio, indicating a positive relationship between capital asset ratio and performance (Berger 1995). Experimental evidence by Demirgüç-Kunt and Huizinga (1999); Goddard et al. (2004) showed that the best banking activities are to maintain a high level of equity equivalent to bank assets at a ratio higher capital tending to face costs lower than funds due to lower possibility of bankruptcy. Porter and Chiou (2013) investigated the relationships between investment capital risks and bank risks and proposed that banks could supplement capital by increasing the risk of the income asset portfolio and off-balance sheet activity, that is, by implementing a more aggressive diversification strategy.

- Ratio of loans to total assets (LTA)

The ratio of total outstanding loans to total assets represents the effects of loan strategy to performance and bank risk adjustment as studied by Sanya and Wolfe (2011); Chiorazzo et al. (2008) and Stiroh (2004a). This ratio increases, meaning that the expansion of credit activities negatively affects the profitability and credit risk will increase accordingly; thus, there will be a positive correlation between total loans to mobilized capital for bank risk.

- Ratio of Non-performing loan (NPL)

Credit quality is often measured by the non-performing loan to total outstanding loan ratio of commercial banks. The bank with a large loss must increase its capital to meet management requirements and minimize the bankruptcy risk. Aggarwal and Jacques (2001) argued that the decline in asset quality is synonymous with a higher degree of risk. Therefore, there is a positive relationship between credit risk and bankruptcy risk and adjusting expected bank profits. Ineffective loans meaning the high non-performing loan ratio reduce asset quality and quickly increase bank risk (González-Hermosillo 1999).

- Liquidity Ratio (LIQ)

To measure bank liquidity, the research uses the loan to deposit ratio (LTD). If this ratio is too high, banks may not have sufficient liquidity to meet the client's capital needs; if this ratio is too low, banks may not achieve the expected revenue. Some empirical studies showed that the higher the liquidity, the higher the bank's asset risk (Demirgüç-Kunt and Huizinga 2010; Norden and Weber 2010).

- Asset growth (GTA)

Asset growth shows that the attitude of managers when facing with bank risk, GTA is calculated by the growth rate of total bank assets. Bank managers often expect more rapid growth and more stable profits (Chiorazzo et al. 2008; Stiroh 2004a). This variable positively affects risks because rapid asset growth can increase the bank's investment portfolio risk. 
Table 1. Research variables.

\begin{tabular}{|c|c|c|c|}
\hline Classification & Variable & Definition & Source \\
\hline \multirow{3}{*}{ Dependent variables } & ROA & Returns on assets & \multirow{2}{*}{ (Chiorazzo et al. 2008; Stiroh 2004a, 2004b) } \\
\hline & ROE & Returns on equity & \\
\hline & Z-score & $\begin{array}{c}\text { Z-score }=\frac{\text { ROA }+ \text { ETA }}{\text { SDROA }} \\
\text { ETA = Equity to Assets } \\
\text { SDROA = ROA standard deviation }\end{array}$ & Mercieca et al. (2007); Chiorazzo et al. (2008); Lee et al. (2014) \\
\hline \multirow[b]{2}{*}{ Independent variables } & INT & Net interest margin/total income & Halling and Hayden (2006) \\
\hline & HHI & $\begin{array}{c}\text { Revenue diversification } \\
\text { HHI } I_{\text {Rev }}=\left(\frac{\text { NON }}{\text { NETOP }}\right)^{2}+\left(\frac{\mathrm{NET}}{\mathrm{NETOO}}\right)^{2} \\
\mathrm{NETOP}=\mathrm{NON}+\mathrm{NET} ; \text { NON represents non-interest income, NET } \\
\text { represents net interest income }\end{array}$ & (Stiroh 2004a, 2004b); Lepetit et al. (2008); Mercieca et al. (2007) \\
\hline \multirow{6}{*}{ Control variable } & SIZE & Natural logarithm of total assets & $\begin{array}{c}\text { Curi et al. (2015); and Berger et al. (2010) } \\
\text { Vallascas and Keasey (2012) }\end{array}$ \\
\hline & LTA & Loan to total Asset ratio & Sanya and Wolfe (2011); Chiorazzo et al. (2008) \\
\hline & ETA & Equity to total Assets ratio & Demirgüç-Kunt and Huizinga (1999); Goddard et al. (2004); Porter and Chiou (2013) \\
\hline & NPL & Non-performing loan/loan outstanding balance & Aggarwal and Jacques (2001); González-Hermosillo (1999) \\
\hline & GTA & Asset growth & (Chiorazzo et al. 2008); Stiroh (2004b) \\
\hline & LIQ & Liquidity ratio = loan outstanding balance/customer deposits & (Demirgüç-Kunt and Huizinga 2010); (Norden and Weber 2010) \\
\hline
\end{tabular}

Source: Summary of the author. 


\section{Results and Discussion}

\subsection{Descriptive Statistics}

This study aims to assess the impact of revenue diversification on risks and performance of 26 Vietnamese commercial banks in the period of 2010-2018. Table 2, descriptive statistics of research variables, including dependent variables and independent variables used in the GMM (Generalized Method of Moments) system model. In which performance is measured by ROA, ROE; bank risk (Z-score); revenue diversification (HHI), net interest income ratio (INT) and control variables (SIZE, LTA, ETA, NPL, GTA, LIQ). Statistical results show that banks' asset use efficiency is approximately $0.7 \%$ on average. Meanwhile, the profitability on average equity is $8.7 \%$. The risk coefficient $Z$-score reaches 40.552 on average, showing that banks in the Vietnamese banking system operate safely under the policy regulation of the State Bank of Vietnam. Average revenue diversification is 0.803 , net interest income accounts for $81.5 \%$ of total revenue (Table 2). This is a challenge for banks in the context of digital economy development. Loan outstanding balance accounts on average of $54.8 \%$ of total loan outstanding balance, the liquidity ratio reaches 0.873 . Non-performing loan ratio of commercial banks is $2.5 \%$ on average; equity/asset ratio reaches $9.2 \%$, ensuring compliance with the regulations of the State Bank of Vietnam and satisfying Basel II standards.

Table 2. Descriptive statistics of research variables.

\begin{tabular}{ccccc}
\hline Variable & Mean & Standard Deviation & Min & Max \\
\hline \multicolumn{5}{c}{ Bank performance } \\
ROA & 0.007 & 0.007 & -0.055 & 0.040 \\
ROE & 0.087 & 0.079 & -0.458 & 0.565 \\
\hline \multicolumn{5}{c}{ Risk of bank } \\
\hline Z-score & 40.522 & 78.975 & 557.332 \\
\hline & \multicolumn{5}{c}{ Independent variables } \\
HHI & 0.736 & 0.134 & 0.984 \\
INT & 0.815 & 0.137 & 0.992 \\
\hline & \multicolumn{5}{c}{0.500} \\
SIZE & 8.038 & Control variable & 0.136 & 9.129 \\
LTA & 0.548 & 0.503 & 0.827 \\
LIQ & 0.873 & 0.138 & 0.915 \\
ETA & 0.092 & 0.255 & 0.145 & 0.255 \\
NPL & 0.025 & 0.040 & 0.363 & 0.114 \\
GTA & 0.521 & 0.017 & 0.023 & 65.375 \\
\hline
\end{tabular}

Source: Financial reporting of 26 Vietnamese commercial banks in the period of 2010-2018. Note: ROA (return on assets); ROE (return on equity); INT (net interest income/total income); HHI (revenue diversification); SIZE (natural logarithm of total assets); LTA (loan to total asset ratio); ETA (equity to total asset ratio); NPL (non-performing loan/loan outstanding balance); GTA (asset growth); LIQ (liquidity ratio = loan outstanding balance/customer deposits).

In this research, dependent variable is performance which was measured using ROA, ROEand bank risk (Z-score); independent variables are revenue diversification and net interest income. In order to solve the research problems, the paper conducts regression of panel data with Pooled model, fixed effects model (FEM) and random effects model (REM). However, the study first conducted a correlation analysis to detect autocorrelation and partially identify multidimensional defects of independent variables affecting regression models. The results of Table 3 show that there is no autocorrelation, facilitating the implementation of subsequent verification steps. 
Table 3. Correlation analysis.

\begin{tabular}{cccccccccccc}
\hline & ROA & ROE & Z-Score & HHI & SIZE & LTA & LIQ & ETA & NPL & INT & GTA \\
\hline ROA & 1 & & & & & & & & & & \\
ROE & 0.798 & 1 & & & & & & & & & \\
Z-score & -0.166 & -0.195 & 1 & & & & & & & & \\
HHI & 0.072 & -0.002 & -0.140 & 1 & & & & & & & \\
SIZE & 0.087 & 0.330 & 0.071 & -0.246 & 1 & & & & & & \\
LTA & 0.185 & 0.215 & -0.018 & 0.091 & 0.430 & 1 & & & & & \\
LIQ & 0.209 & 0.233 & -0.002 & 0.027 & -0.036 & 0.372 & 1 & & & & \\
ETA & 0.266 & -0.189 & -0.084 & 0.114 & -0.647 & -0.170 & 0.028 & 1 & & \\
NPL & -0.024 & -0.107 & 0.019 & -0.038 & -0.122 & 0.009 & -0.098 & 0.140 & 1 & & \\
INT & 0.255 & 0.201 & -0.142 & 0.860 & -0.107 & 0.199 & 0.101 & -0.003 & -0.045 & 1 & \\
GTA & 0.067 & 0.046 & -0.013 & 0.032 & -0.002 & -0.044 & 0.049 & 0.030 & -0.037 & 0.035 & 1
\end{tabular}

Source: Author's calculations. Note: ROA (return on assets); ROE (return on equity) used to measure the performance of commercial banks. Independent variables including: net interest income/total income ratio (INT); revenue diversification $(\mathrm{HHI})$ measured by: $\mathrm{HI}=(\mathrm{NON} / \mathrm{NETOP})^{2}+(\mathrm{NET} / \mathrm{NETOP})^{2} . \mathrm{NETOP}=\mathrm{NON}+\mathrm{NET}$; NON represents non-interest income, NET represents net interest income. Natural logarithm of total assets (SIZE); loan to total asset ratio (LTA); liquidity ratio = loan outstanding balance/customer deposits (LIQ); equity to total assets (ETA); non-performing loan (NPL); asset growth (GTA); Research data is extracted from audited financial statements in the period 2010-2018, published publicly on the electronic portal of banks and publicly announced at the State Securities Commission of Vietnam.

\subsection{The Impact of Revenue Diversification on the Performance of Commercial Banks}

Research conducts regression of the GMM and GMM models to assess the impact of revenue diversification on the performance of the banking system (26 banks), listed banks (12 banks), and unlisted banks (14 banks). Research results are shown in Tables 4 and 5 . The research results show that revenue diversification negatively affects the performance of the Vietnamese banking system measured by ROA and ROE (Lepetit et al. 2008; Mercieca et al. 2007; Stiroh 2004a). The assessment of the role of diversification for listed and unlisted banks performance also gives similar results. Berger et al. (2010) also argued that if banks focused too much on profits, they would reduce diversification. However, this result is contrary to Rossi et al. (2009), arguing that revenue diversification significantly improves overall profitability; Banks with higher revenue diversification, will have higher profitability in both short and long term. Similarly, Meslier et al. (2014) found that revenue diversification, increased the profitability of Philippine banks. Net interest income is the main income source of banks; it is the key motivation of the bank's development in the medium and long term. In addition to credit activities, trading in foreign exchange, gold and securities are affected by fluctuations; thus, it is difficult to avoid the risk of losses, and negatively impacting the bank performance. The bank's revenue from services currently is still mainly from card fees, credit card fees, intermediary services of real estate transaction payment, international payment and ATM and Internet Banking and Mobile Banking fees. Banks continue to raise fees to increase revenue from services. Non-interest activities also have positive results, increasing the proportion of income structure. However, not all banks have a large revenue from services, including large-scale banks and banks developing retail services.

Pressure to implement Basel II forces banks to divert in operations. Credit activities seem to be growing slowly, banks switch to develop services to increase revenue, but it is difficult to expect strong growth in a short time. Some large-scale banks that lead the retail sector, show signs of declining revenue from services. Growth, as well as contributions from service activities, is not commensurate with potential; although there are many positive points, they are not enough to cover risks from net interest income activities. The system of Vietnamese commercial banks needs to improve and promote the non-credit service quality, especially e-banking services in the context of constantly changing consumer habits and increasing technology acceptance level. It is necessary to restructure revenue between credit and non-credit services effectively in accordance with the financial capacity and development objectives and business development orientation of each bank, making the most of supporting policies from the State Bank of Vietnam and the government. Promote implementation of comprehensive and breakthrough solutions to manage credit growth stably, effectively and minimize risks as well as ensure the safety of the banking system. 
Table 4. Pooled, Fixed effect model—the impact of revenue diversification on performance.

\begin{tabular}{|c|c|c|c|c|c|c|c|c|c|c|c|c|}
\hline \multirow{3}{*}{ Variable } & \multicolumn{4}{|c|}{ Banking System (26) } & \multicolumn{4}{|c|}{ Listed Bank (12) } & \multicolumn{4}{|c|}{ Unlisted Banks (14) } \\
\hline & \multicolumn{2}{|c|}{ ROA } & \multicolumn{2}{|c|}{ ROE } & \multicolumn{2}{|c|}{ ROA } & \multicolumn{2}{|c|}{ ROE } & \multicolumn{2}{|c|}{ ROA } & \multicolumn{2}{|c|}{ ROE } \\
\hline & Pooled & Fixed Effect & Pooled & Fixed Effect & Pooled & Fixed Effect & Pooled & Fixed Effect & Pooled & Fixed Effect & Pooled & Fixed Effect \\
\hline \multirow[t]{2}{*}{$\mathrm{HHI}$} & -0.0295 * & -0.0354 * & $-0.2702 *$ & $-0.3172 *$ & $-0.0626^{*}$ & -0.0768 * & $-0.5159 *$ & -0.6968 * & 0.0068 & 0.0068 & 0.0074 & 0.1186 \\
\hline & 0.0059 & 0.0079 & 0.0689 & 0.0902 & 0.0073 & 0.0090 & 0.0786 & 0.0979 & 0.0067 & 0.0088 & 0.0991 & 0.1292 \\
\hline \multirow[t]{2}{*}{ SIZE } & $0.0069 *$ & $0.0100 *$ & 0.0633 * & 0.0302 & $0.0110 *$ & $0.0134 *$ & $0.1154 *$ & $0.0831 * *$ & 0.0007 & -0.0003 & -0.0214 & $-0.0896^{* *}$ \\
\hline & 0.0012 & 0.0025 & 0.0140 & 0.0291 & 0.0021 & 0.0039 & 0.0224 & 0.0384 & 0.0014 & 0.0031 & 0.0209 & 0.0456 \\
\hline \multirow{2}{*}{ LTA } & -0.0044 & -0.0053 & -0.0626 & -0.0432 & -0.0213 * & $-0.0242 * *$ & $-0.2496^{*}$ & $-0.2528 *$ & -0.0030 & -0.0059 & -0.0351 & 0.0078 \\
\hline & 0.0036 & 0.0048 & 0.0424 & 0.0545 & 0.0065 & 0.0083 & 0.0692 & 0.0865 & 0.0033 & 0.0051 & 0.0479 & 0.0742 \\
\hline \multirow[t]{2}{*}{ LIQ } & $0.0049 *$ & 0.0079 * & $0.0705 *$ & 0.1139 * & 0.0044 & $0.0192 *$ & $0.0642 * *$ & $0.2157^{*}$ & $0.0046^{*}$ & $0.0044^{* *}$ & 0.0606 * & 0.0815 * \\
\hline & 0.0017 & 0.0022 & 0.0198 & 0.0253 & 0.0032 & 0.0049 & 0.0345 & 0.0476 & 0.0015 & 0.0019 & 0.0214 & 0.0281 \\
\hline \multirow[t]{2}{*}{ ETA } & $0.1129 *$ & 0.1001 * & 0.2097 & -0.1647 & 0.1824 * & $0.1223 *$ & $0.7100 *$ & -0.0377 & $0.0488^{*}$ & $0.0319 * * *$ & $-0.4645^{* *}$ & $-0.7668 *$ \\
\hline & 0.0128 & 0.0156 & 0.1496 & 0.1792 & 0.0200 & 0.0253 & 0.2141 & 0.2031 & 0.0137 & 0.0169 & 0.2017 & 0.2478 \\
\hline \multirow{2}{*}{ NPL } & -0.0090 & 0.0297 & -0.1766 & 0.1741 & -0.0439 & -0.0183 & -0.5856 & -0.0511 & $0.0439 * *$ & $0.0491 * *$ & 0.4892 & 0.1365 \\
\hline & 0.0235 & 0.0252 & 0.2758 & 0.2890 & 0.0417 & 0.0770 & 0.4471 & 0.7309 & 0.0207 & 0.0225 & 0.3050 & 0.3299 \\
\hline \multirow[t]{2}{*}{ INT } & $0.0410 *$ & 0.0458 * & $0.3656^{*}$ & 0.3915 * & $0.0855 *$ & $0.0967^{*}$ & $0.7182 *$ & $0.8706^{*}$ & 0.0015 & -0.0044 & 0.0501 & -0.1018 \\
\hline & 0.0057 & 0.0066 & 0.0667 & 0.0754 & 0.0079 & 0.0120 & 0.0851 & 0.1060 & 0.0060 & 0.0069 & 0.0879 & 0.1012 \\
\hline \multirow[t]{2}{*}{ GTA } & 0.0000 & 0.0001 & 0.0003 & 0.0011 & 0.0000 & 0.0001 & -0.0005 & $0.0005^{* *}$ & 0.0030 * & $0.0033^{* *}$ & $0.0319 * * *$ & $0.0449 * *$ \\
\hline & 0.0001 & 0.0001 & 0.0010 & 0.0010 & 0.0001 & 0.0000 & 0.0009 & 0.0002 & 0.0013 & 0.0013 & 0.0192 & 0.0196 \\
\hline \multirow[t]{2}{*}{ Intercept factor } & -0.0721 & -0.0983 & -0.5634 & -0.3071 & -0.1113 & -0.1374 & -1.0079 & -0.8094 & -0.0152 & 0.0004 & 0.1744 & 0.7439 \\
\hline & 0.0109 & 0.0207 & 0.1275 & 0.2378 & 0.0176 & 0.0324 & 0.1891 & 0.2912 & 0.0132 & 0.0258 & 0.1945 & 0.3789 \\
\hline Observation & 234 & 234 & 234 & 234 & 108 & 108 & 108 & 108 & 126 & 126 & 126 & 126 \\
\hline Group & 26 & 26 & 26 & 26 & 13 & 13 & 13 & 13 & 14 & 14 & 14 & 14 \\
\hline R2 & 0.3884 & 0.3276 & 0.2776 & 0.2342 & 0.6666 & 0.5165 & 0.5740 & 0.4724 & 0.3302 & 0.3359 & 0.1707 & 0.1031 \\
\hline
\end{tabular}

(n) ${ }^{* * *}$ represent significance at the $1 \%, 5 \%$ and $10 \%$ levels, respectively. Note: ROA (Return on assets); ROE (Return on equity) used to measure the performance of commercial banks. Independent variables including: net interest income/total income ratio (INT); revenue diversification $(\mathrm{HHI})$ measured by: $\mathrm{HI}=(\mathrm{NON} / \mathrm{NETOP})^{2}+(\mathrm{NET} / \mathrm{NETOP})^{2}$. NETOP $=\mathrm{NON}+$ NET; NON represents non-interest income, NET represents net interest income. Natural logarithm of total assets (SIZE); loan to total asset ratio $($ LTA); liquidity ratio = loan outstanding balance/customer deposits (LIQ); equity to total asset ratio (ETA); non-performing loan ratio (NPL); asset growth (GTA). Research data is extracted from audited financial statements in the period 2010-2018, published publicly on the electronic portal of banks and publicly announced at the State Securities Commission of Vietnam. 
Table 5. GMM model—the impact of revenue diversification on performance.

\begin{tabular}{|c|c|c|c|c|c|c|c|c|c|c|c|c|}
\hline \multirow{3}{*}{ Variable } & \multicolumn{4}{|c|}{ Banking System (26) } & \multicolumn{4}{|c|}{ Listed Bank (12) } & \multicolumn{4}{|c|}{ Unlisted Banks (14) } \\
\hline & \multicolumn{2}{|c|}{ ROA } & \multicolumn{2}{|c|}{ ROE } & \multicolumn{2}{|c|}{ ROA } & \multicolumn{2}{|c|}{ ROE } & \multicolumn{2}{|c|}{ ROA } & \multicolumn{2}{|c|}{ ROE } \\
\hline & GMM & $\begin{array}{l}\text { GMM for } \\
\text { System }\end{array}$ & GMM & $\begin{array}{l}\text { GMM for } \\
\text { System }\end{array}$ & GMM & $\begin{array}{l}\text { GMM for } \\
\text { System }\end{array}$ & GMM & $\begin{array}{l}\text { GMM For } \\
\text { System }\end{array}$ & GMM & $\begin{array}{l}\text { GMM for } \\
\text { System }\end{array}$ & GMM & $\begin{array}{l}\text { GMM for } \\
\text { System }\end{array}$ \\
\hline \multirow[t]{2}{*}{$\mathrm{HHI}$} & $0.0258 *$ & $-0.0337^{*}$ & $0.2598 * *$ & $-0.2747^{*}$ & 0.0220 & -0.0620 * & $-0.0445^{*}$ & $-0.5633 *$ & 0.0073 & $-0.0483 * *$ & 0.0910 & -0.1853 * \\
\hline & 0.0086 & 0.0049 & 0.1290 & 0.0686 & 0.0405 & 0.0096 & 0.4597 & 0.1060 & 0.0087 & 0.0208 & 0.0789 & 0.0736 \\
\hline \multirow[t]{2}{*}{ SIZE } & $0.0185^{*}$ & $0.0057^{*}$ & 0.1403 * & 0.0496 * & $0.0207^{*}$ & $0.0128 *$ & 0.1185 & $0.0983^{* * *}$ & $0.0163^{* *}$ & -0.0043 & 0.1965 * & 0.0648 \\
\hline & 0.0051 & 0.0012 & 0.0446 & 0.0142 & 0.0037 & 0.0035 & 0.0379 & 0.0533 & 0.0059 & 0.0053 & 0.0616 & 0.0506 \\
\hline \multirow[t]{2}{*}{ LTA } & -0.0140 & -0.0036 & $-0.1693^{* *}$ & $-0.0692 *$ & -0.0223 & $-0.0258^{*}$ & $-0.1748^{* *}$ & $-0.2776^{* *}$ & -0.0094 & -0.0009 & -0.1139 & -0.0191 \\
\hline & 0.0094 & 0.0023 & 0.0764 & 0.0275 & 0.0143 & 0.0085 & 0.1452 & 0.1137 & 0.0096 & 0.0019 & 0.0845 & 0.0302 \\
\hline \multirow{2}{*}{ LIQ } & 0.0159 ** & $0.0052 *$ & 0.2053 * & $0.0742 *$ & $0.0177^{* * *}$ & $0.0106 *$ & 0.2137 & 0.1193 * & $0.0094 *$ & $0.0051 *$ & $0.1273 *$ & $0.0980 *$ \\
\hline & 0.0059 & 0.0011 & 0.0550 & 0.0111 & 0.0085 & 0.0038 & 0.0915 & 0.0305 & 0.0031 & 0.0014 & 0.0216 & 0.0253 \\
\hline \multirow[t]{2}{*}{ ETA } & $0.1381 *$ & $0.1097^{*}$ & $0.4423 * *$ & 0.0396 & $0.1768 *$ & $0.1861 *$ & 0.4128 & 0.7597 & $0.1104^{* *}$ & 0.0197 & $0.6750 * * *$ & 0.2105 \\
\hline & 0.0318 & 0.0100 & 0.1932 & 0.1847 & 0.0176 & 0.0353 & 0.2628 & 1.0128 & 0.0494 & 0.0461 & 0.3621 & 0.4195 \\
\hline \multirow[t]{2}{*}{ NPL } & 0.0270 & $-0.0030 *$ & 0.1746 & $-0.2440 *$ & -0.0451 & 0.0569 & -0.4725 & 0.1890 & 0.0633 & $0.0800 * * *$ & 0.4399 & 0.3005 \\
\hline & 0.0309 & 0.0350 & 0.3600 & 0.2464 & 0.0761 & 0.1213 & 0.8594 & 2.0757 & 0.0360 & 0.0476 & 0.3121 & 0.3089 \\
\hline \multirow[t]{2}{*}{ INT } & -0.0095 & $0.0443^{*}$ & -0.1568 & $0.3277^{*}$ & -0.0047 & 0.0870 * & 0.1249 & 0.7680 * & -0.0037 & 0.0387 * & -0.0414 & -0.0540 \\
\hline & 0.0007 & 0.0000 & 0.0060 & 0.0006 & 0.0377 & 0.0001 & 0.4539 & 0.0981 & 0.0050 & 0.0151 & 0.0505 & 0.0378 \\
\hline \multirow[t]{2}{*}{ GTA } & -0.0003 & $-0.0631 * *$ & 0.0061 & 0.0009 & 0.0003 & 0.0001 & 0.0078 & 0.0010 & -0.0008 & 0.0007 & 0.0035 & 0.0322 \\
\hline & 0.0007 & 0.0109 & 0.0060 & 0.0006 & 0.0004 & 0.0001 & 0.0061 & 0.0008 & 0.0023 & 0.0022 & 0.0210 & 0.0288 \\
\hline \multirow[t]{2}{*}{ Intercept factor } & & -0.0676 & & -0.4039 & & -0.1341 & & -0.9222 & & 0.0355 & & -0.6603 \\
\hline & & 0.0088 & & 0.1324 & & 0.0335 & & 0.4486 & & 0.0515 & & 0.4678 \\
\hline Observation & 234 & 234 & 234 & 234 & 108 & 108 & 108 & 108 & 126 & 126 & 126 & 126 \\
\hline Group & 26 & 26 & 26 & 26 & 13 & 13 & 13 & 13 & 14 & 14 & 14 & 14 \\
\hline F-statistic & 4.90 & & 7.63 & & 45.42 & & 16.05 & & & & 42.30 & \\
\hline Wald Test & & 322.51 & & 205.69 & & 496.45 & & 1822.82 & & 87.99 & & 499.41 \\
\hline $\mathrm{AR}(2)$ & 0.43 & & 0.11 & & 0.56 & & 0.05 & & -0.39 & & 0.55 & \\
\hline Sargan test & 11.04 & & 6.85 & & 6.80 & & 7.03 & & 12.01 & & 6.91 & \\
\hline Hansen & 16.70 & & 16.95 & & 4.80 & & 7.45 & & 1.53 & & 2.49 & \\
\hline
\end{tabular}

$*{ }^{* *}$ and ${ }^{* * *}$ represent significance at the $1 \%, 5 \%$ and $10 \%$ levels, respectively. Note: ROA (return on assets); ROE (return on equity) used to measure the performance of commercial banks. Independent variables including: net interest income/total income ratio (INT); revenue diversification $(\mathrm{HHI})$ measured by: $\mathrm{HI}=(\mathrm{NON} / \mathrm{NETOP})^{2}+(\mathrm{NET} / \mathrm{NETOP})^{2}$. NETOP $=\mathrm{NON}+$ NET; NON represents non-interest income, NET represents net interest income. Natural logarithm of total assets (SIZE); loan to total asset ratio $(\mathrm{LTA})$; liquidity ratio = loan outstanding balance/customer deposits (LIQ); equity to total asset ratio (ETA); non-performing loan ratio (NPL); asset growth (GTA). Research data is extracted from audited financial statements in the period 2010-2018, published publicly on the electronic portal of banks and publicly announced at the State Securities Commission of Vietnam. 
The larger the bank's asset size (SIZE), the more likely it is to increase revenue and profit, grow strongly in assets and be able to use capital more efficiently than small banks. Berger et al. (2010) and Curi et al. (2015) also found that both bank scale and squared bank regression increased cost efficiency, suggesting that large banks managed cost more efficiently than small banks, meaning their business performance was better. The banks with good liquidity are usually large-scale banks with state capital. The liquidity of these banks is usually better than the rest. In fact, the better the banking liquidity, the higher the profitability of the credit institutions, along with an increasing credit risk. The leaders of the banks all have the same view that high risk provision is made because the non-performing loan ratio has not decreased much over the same period because the new non-performing loan is arisen in the macroeconomic context that has not had much improvement, business operations of the bank still face many difficulties. Moreover, for restructured debt, when the repayment period expired, could not be paid by many customers. It can be seen that the views on debtors-creditors in Vietnam are unusual, leading to difficulties in dealing with non-performing loan. In addition, the legal framework is incomplete, overlapping and contradictory; "criminalization" thinking of cases of losing public property is still heavy. Meanwhile, the handling of secured assets is complicated; the debt trading market has not yet been formed.

In general, banks satisfy the Basel II standard and the state bank regulation on Equity to Total Asset Ratio (ETA), which is a higher, reducing the dependence from funding flows and make profits of banks higher. This shows the bank's ability to absorb losses and handle risks. Banks with capital strength will face lower bankruptcy risk costs, thus, risk provisioning is also lower (Berger 1995; Bourke 1989; Hassan and Bashir 2003). Vietnamese banks have made great progress and made positive contributions to the socioeconomic development. However, along with that development, the shortcomings in the management of banks as well as difficulties also arise in many aspects of operation, including the issue of equity-that is the capital component which is extremely important in operating capital of commercial banks. Therefore, it is necessary to have strong changes in the recognition and management of bank equity from the state management agencies as well as commercial banks.

\subsection{The Impact of Revenue Diversification on the Risk of Commercial Banks}

Similar to Section 4.2, in this section, the study conducts regression of the GMM model and GMM for system for Panels data to assess the impact of revenue diversification on risk of Vietnamese commercial banking system. Research results for the Pooled OLS, Fixed effects method (FEM) and GMM Model are shown in Tables 6 and 7. Experimental research shows that revenue diversification negatively affects the Z-Score risk measurement index, which means that the higher the revenue diversification, the higher the bank risk. This seems inconsistent with previous studies by (Mercieca et al. 2007); (Chiorazzo et al. 2008) and (Lee et al. 2014). However, it is consistent with the research of Stiroh and Rumble (2006); the benefit of revenue diversification is offset by the increase in non-interest activity. On the other hand, it also adjusts the risk of banks. Demirgüç-Kunt and Huizinga (2010) and Li and Zhang (2013) argued that a higher level of increased non-interest income means increased revenue diversification leads to higher risks for banks. This shows the weakness and lack of experience of the banking system in building a reasonable profit transformation model. The current bank revenue diversification is passive and slow to change; economic efficiency is not high and still depends heavily on credit activities. 
The higher the Equity to total asset ratio (ETA) variable, the lower the bankruptcy risk of commercial banks. This higher ratio helps to reduce the dependence from external fund inflows and banks' profits higher, indicating the potential risk to the bank's credit activities; banks should actively fund to absorb losses and handle risks. Banks with capital strength will face lower bankruptcy risk costs, thus, risk provisioning is also lower (Berger 1995; Bourke 1989; Hassan and Bashir 2003). Experimental evidence by Demirgüç-Kunt and Huizinga (1999) and Goddard et al. (2004) shows that banking operations are best to maintain high levels of equity to total asset ratio because banks with the high ratio of capitalized tend to face less risk of bankruptcy. However, Porter and Chiou (2013) had the same view with this research result given that banks supplemented capital by increasing the risk of the income asset portfolio and off-balance sheet activities. The Vietnamese banking system has made great progress, but there are still shortcomings in the management of banks as well as difficulties that arise in many aspects, including the issue of equity. This is a capital component, which is extremely important in operating capital of commercial banks. Therefore, it is necessary to have strong changes in the recognition and management of bank equity from the state management agencies, as well as commercial banks.

Table 6. Pooled fixed effect model—the impact of revenue diversification on bank risk.

\begin{tabular}{ccccccc}
\hline \multirow{2}{*}{ Variable } & \multicolumn{5}{c}{ Z-Score } \\
\cline { 2 - 7 } & \multicolumn{2}{c}{ Banking System (26) } & \multicolumn{2}{c}{ Listed Bank (12) } & \multicolumn{2}{c}{ Unlisted Banks (14) } \\
\cline { 2 - 6 } HHI & Pooled & Fixed Effect & Pooled & Fixed Effect & Pooled & Fixed Effect \\
\hline \multirow{2}{*}{ SIZE } & -16.9592 & $-73.4480^{* *}$ & -4.0018 & $12.7742 * *$ & -60.2815 & $-120.0412^{* * *}$ \\
& 80.3413 & 35.2882 & 17.3641 & 6.3749 & 165.1179 & 69.0823 \\
LTA & 2.0199 & $-44.6604^{*}$ & $12.8728 *$ & $-8.3746^{*}$ & 49.0409 & $-113.4627^{*}$ \\
& 16.3511 & 11.3639 & 4.9417 & 1.9541 & 34.7700 & 24.3848 \\
LIQ & -12.3307 & $-7.7556^{* *}$ & -21.3642 & $10.1551 * *$ & 0.6757 & -12.2934 \\
& 49.4180 & 21.3316 & 15.2882 & 4.2530 & 79.7648 & $39.6514^{*}$ \\
ETA & 7.4200 & $22.6653 * *$ & 10.5988 & $7.5995 *$ & 1.2986 & 30.7564 \\
& 23.1193 & 9.8921 & 7.6130 & 2.5419 & 35.5776 & 15.0461 \\
NPL & -158.2371 & 146.6115 & 41.7001 & $161.9017 *$ & -1.2293 & -66.1437 \\
& 174.3350 & 70.0892 & 47.3005 & 16.7084 & 335.9920 & 132.4654 \\
INT & 131.4755 & 83.9041 & 112.3704 & $79.8889 *$ & -249.7761 & -35.9672 \\
& 321.3336 & 113.0256 & 98.7605 & 27.4320 & 508.0504 & 176.3655 \\
GTA & -64.5546 & $108.6839 *$ & $32.9859 * * *$ & -5.0104 & -107.0849 & $172.7163 *$ \\
& 77.6919 & 29.4989 & 18.7928 & 5.6554 & 146.3749 & 54.0877 \\
Intercept & -0.1333 & -0.1017 & -0.1624 & 0.0075 & 51.7277 & -8.2381 \\
factor & 1.2220 & 0.3890 & 0.2018 & 0.0504 & 31.9143 & 10.4810 \\
Observation & 101.0566 & 333.9465 & -108.9888 & 60.6610 & -200.9881 & 876.6272 \\
Group & 23.5109 & 92.9856 & 41.7590 & 16.1334 & 324.0319 & 202.5602 \\
R2 & 234 & 234 & 234 & 234 & 234 & 234 \\
\hline \multirow{2}{*}{ * } & 0.0285 & 0.2843 & 0.1597 & 0.2363 & 0.1214 & 0.0673 \\
\hline
\end{tabular}

$*{ }^{* *}$ and ${ }^{* * *}$ represent significance at the $1 \%, 5 \%$ and $10 \%$ levels, respectively. Note: bank risk measured by $\mathrm{Z}$-score $=($ ROA + ETA $) / S D R O A ; E T A=$ equity/asset, SDROA $=$ ROA standard deviation. Independent variables including: net interest income/total income ratio (INT); Revenue diversification (HHI) measured by: $\mathrm{HHI}=(\mathrm{NON} / \mathrm{NETOP})^{2}+(\mathrm{NET} / \mathrm{NETOP})^{2} . \mathrm{NETOP}=\mathrm{NON}+\mathrm{NET} ; \mathrm{NON}$ represents non-interest income, $\mathrm{NET}$ represents net interest income. Natural logarithm of total assets (SIZE); loan to total asset ratio (LTA); equity to total asset ratio (ETA); non-performing loan (NPL); asset growth (GTA); liquidity ratio = loan outstanding balance/customer deposits (LIQ). Research data is extracted from audited financial statements in the period 2010-2018, published publicly on the electronic portal of banks and publicly announced at the State Securities Commission of Vietnam. 
Table 7. GMM model—-the impact of revenue diversification on bank risk.

\begin{tabular}{|c|c|c|c|c|c|c|}
\hline \multirow{3}{*}{ Variable } & \multicolumn{6}{|c|}{ Z-Score } \\
\hline & \multicolumn{2}{|c|}{ Banking System (26) } & \multicolumn{2}{|c|}{ Listed Bank (12) } & \multicolumn{2}{|c|}{ Unlisted Banks (14) } \\
\hline & GMM & GMM for System & GMM & GMM for System & GMM & GMM for System \\
\hline \multirow[t]{2}{*}{ HHI } & 67.4423 & $-27.0381 *$ & 5.3984 & $-50.5815^{*}$ & -15.0852 & $-138.2848^{* *}$ \\
\hline & 62.7267 & 5.9107 & 23.7921 & 18.5574 & 60.0802 & 63.8694 \\
\hline \multirow[t]{2}{*}{ SIZE } & -53.1374 & -0.9251 & $-14.3257 *$ & $11.2364^{* *}$ & -211.3938 & $71.1272 *$ \\
\hline & 45.8868 & 4.3233 & 2.7267 & 4.6223 & 150.8904 & 28.0055 \\
\hline \multirow[t]{2}{*}{ LTA } & -28.2702 & -11.7999 & 19.3898 & -18.2607 & -49.0586 & 19.0482 \\
\hline & 43.4823 & 9.6310 & 10.8840 & 19.4630 & 65.3754 & 49.5226 \\
\hline \multirow[t]{2}{*}{ LIQ } & 23.6764 & $12.4501 * * *$ & $12.5640 * *$ & -6.1353 & 76.2397 & -3.1114 \\
\hline & 24.6322 & 6.8079 & 5.0670 & 13.2196 & 52.9093 & 12.4002 \\
\hline \multirow[t]{2}{*}{ ETA } & -26.0547 & -21.7340 & 123.5465 * & $140.7288^{*}$ & -534.9738 & $668.2044 *$ \\
\hline & 230.9513 & 55.9014 & 36.6224 & 50.2955 & 621.2281 & 196.4053 \\
\hline \multirow[t]{2}{*}{ NPL } & 116.3247 & $112.3741^{* * *}$ & $107.8816^{* * *}$ & -602.4066 & -254.4825 & -560.2787 \\
\hline & 151.6507 & 62.2863 & 56.9173 & 436.3195 & 181.4965 & 739.3324 \\
\hline \multirow{2}{*}{ INT } & -22.5291 & -11.5127 & 2.7492 & 89.7978 * & 65.2403 & $-118.3618 *$ \\
\hline & 1.1798 & 0.1422 & 22.6803 & 28.0515 & 63.4773 & 38.7996 \\
\hline \multirow[t]{2}{*}{ GTA } & 67.4423 & 61.6590 & -0.2922 & -0.3418 & -29.0838 & $39.6196^{* * *}$ \\
\hline & 62.7267 & 43.5201 & 0.5190 & 0.4346 & 29.2333 & 22.0640 \\
\hline Intercept & & -27.0381 & & -85.9714 & & -590.5181 \\
\hline factor & & 5.9107 & & 51.9649 & & 250.3589 \\
\hline Observation & 234 & 234 & 108 & 108 & 126 & 126 \\
\hline Group & 26 & 26 & 13 & 13 & 14 & 14 \\
\hline F-statistic & 6.61 & & 17.74 & & 137.16 & \\
\hline Wald Test & & 207.01 & & 198.80 & & 160.11 \\
\hline $\mathrm{AR}(2)$ & 1.03 & & 0.21 & & 1.08 & \\
\hline Sargan test & 35.78 & & 17.09 & & 31.13 & \\
\hline Hansen & 10.50 & & 4.76 & & 2.24 & \\
\hline
\end{tabular}

$*^{* * *}$ and ${ }^{* * *}$ represent significance at the $1 \%, 5 \%$ and $10 \%$ levels, respectively. Note: bank risk measured by Z-score $=($ ROA + ETA $) /$ SDROA; ETA $=$ Equity/total asset, SDROA $=$ ROA standard deviation. Independent variables including: net interest income/total income ratio (INT); revenue diversification (HHI) measured by: $\mathrm{HHI}=(\mathrm{NON} / \mathrm{NETOP})^{2}+(\mathrm{NET} / \mathrm{NETOP})^{2} . \mathrm{NETOP}=\mathrm{NON}+\mathrm{NET} ; \mathrm{NON}$ represents non-interest income, NET represents net interest income. Natural logarithm of total assets (SIZE); loan to total asset ratio (LTA); equity to total asset ratio (ETA); non-performing loan (NPL); asset growth (GTA); liquidity ratio = loan outstanding balance/customer deposits (LIQ). Research data is extracted from audited financial statements in the period 2010-2018, published publicly on the electronic portal of banks and publicly announced at the State Securities Commission of Vietnam.

The research results of the Loan to Total asset ratio (LTA) are similar to those of Sanya and Wolfe (2011); Chiorazzo et al. (2008) and Stiroh (2004b), suggesting that the increase in this ratio means that the expansion of credit activities will increase credit risk accordingly; hence, there will be a positive correlation between total loan on capital mobilized to bank risk. The use of the relationship between loan and deposit is as a measure of liquidity is based on the premise that credit is the least flexible asset among the bank's profitable assets. Therefore, when the bank's liquidity decreases, bank risk tends to increase. The good management of credit risk (or reducing non-performing loan ratio) currently will help reduce the provision rate in the future.

The Loan to Deposit ratio (LIQ) is one of the commonly used liquidity ratios in many countries in banking management and monitoring activities to improve the quality of liquidity risk management of the banks, ensure the stability and safety of the system. The research results show that although liquidity increases, the banking system remains stable and safe, unlike Demirgüç-Kunt and Huizinga (2010) and (Norden and Weber 2010). This shows that the positive signal from the banking system in ensuring liquidity, safety to help banks prevent risks. Liquidity risk of Vietnamese commercial banks is minimized thanks to the SBV's efforts in continuously reducing the interest rate ceiling and encouraging large banks to support small banks. The signs of assessment of improving liquidity risk are reflected in Interbank Offered Rate rapidly increasing, mainly in a short time, reduced overnight transactions, no public interest rate races and no sign of a decline in deposits even if banks are forced to restructure. Banks have taken the initiative and flexible solutions to enhance capital mobilization as well as restructuring capital to ensure safety ratios such as short-term, medium and long-term loan 
rate to be $40 \%$ and must prepare to raise capital to satisfy Basel II standard. The interest rate level depends on the inflation variable and exchange rate. Therefore, the State Bank of Vietnam should maintain the interest rate level as current. Banks with good capital conditions should reduce interest rates, support customers and not expect a large-scale interest rate reduction. In addition, banks need to diversify products to mobilize deposits, be flexible in deposit terms, improve service quality and develop networks to reach and meet customers' needs better.

In theory, the larger the scale of the bank, the greater the capacity to withstand the risk (Lehar 2005; Poghosyan and Čihak 2011). However, this is not true for the reality in Vietnam, where large-scale banks have declining asset quality while the scale of credits and customers increases rapidly. Meanwhile, risk management capacity, control system, and forecast are still limited. In recent times, banks have had many changes in lending policies as well as appraising, monitoring and controlling disbursed loans to customers to ensure the NPL ratio remains less than 3\%. However, the handling of non-performing loans is still a difficult issue. Risks to operations may stem from credit policies, unsatisfactory processes, people and internal systems, inactivity or external actors. The risks may be due to the information technology system, internal fraud, organizational model, regulations and the process of handling the work. Banks need to strengthen credit risk prevention, raise a cautious sense of loans to customers, really care about controlling loans after disbursing such as reviewing and improving cross monitoring procedures in bank for loans, thereby helping banks identify problematic loans and negotiate with customers in order to avoid transferring debt groups, avoid profiteering activities for the bank's loan officers.

\section{Check Robust}

Because banks can choose whether or not to diversify, the issue of endogeneity between diversification and bank performance is regularly discussed in the literature (Berger et al. 2010; Elsas et al. 2010; Laeven and Levine 2007). Hence, I test the robustness of the results by controlling for possible endogeneity, following Elsas et al. (2010) approach of using lagged instrumental variables. Although lagging variables are not fully exogenous, they are predetermined. To be valid instruments, these variables must be correlated with one endogenous variable (diversification) but not the other (bank efficiency). Tables 8-10 shows the results of estimations using lagged diversifications as the instrumental variables for current diversifications, and employing a two-stage least squares (2SLS) estimated. The tables also present the results of the Hansen test for endogeneity (De-Min 1973; Hausman 1978). According to Schultz et al. (2010), the existence of endogeneity would bias fixed-effects parameter estimates, and other estimators would need to be used. On the other hand, if endogeneity does not exist, estimates that deal with endogeneity such as the 2SLS would be less efficient than the fixed-effects panel regression. Most of the tests for the validity of instrumental variables (Sargan test) and the second-order autocorrelation of residuals (Arellano-Bond test) give the evidence not to reject the null hypothesis at the significance level of $5 \%$. Hence, we could rely on the regression results for decision making. 
Table 8. Poole, fixed effect model—Check Robustness of ROA, ROE regression.

\begin{tabular}{|c|c|c|c|c|c|c|c|c|c|c|c|c|}
\hline \multirow{3}{*}{ Variable } & \multicolumn{4}{|c|}{ Banking System (26) } & \multicolumn{4}{|c|}{ Listed Bank (12) } & \multicolumn{4}{|c|}{ Unlisted Banks (14) } \\
\hline & \multicolumn{2}{|c|}{ ROA } & \multicolumn{2}{|c|}{ ROE } & \multicolumn{2}{|c|}{ ROA } & \multicolumn{2}{|c|}{ ROE } & \multicolumn{2}{|c|}{ ROA } & \multicolumn{2}{|c|}{ ROE } \\
\hline & Pooled & Fixed Effect & Pooled & Fixed Effect & Pooled & Fixed Effect & Pooled & Fixed Effect & Pooled & Fixed Effect & Pooled & Fixed Effect \\
\hline \multirow[t]{2}{*}{$\mathrm{HHI}$} & -0.0295 & -0.0354 & -0.2702 & -0.3172 & $-0.0626^{*}$ & $-0.0768 *$ & $-0.5159 *$ & $-0.6968 *$ & 0.0068 & 0.0068 & 0.0074 & 0.1186 \\
\hline & 0.0206 & 0.0265 & 0.1672 & 0.2426 & 0.0073 & 0.0090 & 0.0786 & 0.0979 & 0.0059 & 0.0076 & 0.0961 & 0.0828 \\
\hline \multirow[t]{2}{*}{ SIZE } & $0.0069 *$ & 0.0100 ** & $0.0633 *$ & 0.0302 & $0.0110 *$ & $0.0134^{*}$ & $0.1154 *$ & $0.0831^{* *}$ & 0.0007 & -0.0003 & -0.0214 & -0.0896 \\
\hline & 0.0014 & 0.0049 & 0.0222 & 0.0658 & 0.0021 & 0.0039 & 0.0224 & 0.0384 & 0.0017 & 0.0054 & 0.0474 & 0.1416 \\
\hline \multirow[t]{2}{*}{ LTA } & -0.0044 & -0.0053 & -0.0626 & -0.0432 & -0.0213 * & $-0.0242 * *$ & -0.2496 * & $-0.2528 *$ & -0.0030 & -0.0059 & -0.0351 & 0.0078 \\
\hline & 0.0038 & 0.0054 & 0.0432 & 0.0754 & 0.0065 & 0.0083 & 0.0692 & 0.0865 & 0.0030 & $0.0068^{* * *}$ & 0.0388 & 0.0774 \\
\hline \multirow[t]{2}{*}{ LIQ } & $0.0049 *$ & $0.0079 * *$ & 0.0705 * & $0.1139 *$ & 0.0044 & $0.0192 *$ & $0.0642 * *$ & $0.2157^{*}$ & $0.0046^{*}$ & 0.0044 & 0.0606 ** & $0.0815 * *$ \\
\hline & 0.0015 & 0.0033 & 0.0178 & 0.0350 & 0.0032 & 0.0049 & 0.0345 & 0.0476 & 0.0016 & 0.0021 & 0.0253 & 0.0369 \\
\hline \multirow[t]{2}{*}{ ETA } & $0.1129 *$ & $0.1001 *$ & 0.2097 & -0.1647 & 0.1824 * & $0.1223 *$ & 0.7100 * & -0.0377 & $0.0488 *$ & 0.0319 & -0.4645 & -0.7668 \\
\hline & 0.0186 & 0.0304 & 0.2593 & 0.4240 & 0.0200 & 0.0253 & 0.2141 & 0.2031 & 0.0191 & 0.0269 & 0.5113 & 0.7437 \\
\hline \multirow[t]{2}{*}{ NPL } & -0.0090 & 0.0297 & -0.1766 & 0.1741 & -0.0439 & -0.0183 & -0.5856 & -0.0511 & 0.0439 & 0.0491 & $0.4892 * * *$ & 0.1365 \\
\hline & 0.0279 & 0.0475 & 0.2656 & 0.3555 & 0.0417 & 0.0770 & 0.4471 & 0.7309 & 0.0281 & 0.0425 & 0.2889 & 0.3633 \\
\hline \multirow[t]{2}{*}{ INT } & 0.0410 * & 0.0458 & $0.3656 * *$ & 0.3915 & $0.0855 *$ & $0.0967 *$ & $0.7182 *$ & $0.8706^{*}$ & 0.0015 & -0.0044 & 0.0501 & $-0.1018^{* * *}$ \\
\hline & 0.0226 & 0.0300 & 0.1822 & 0.2723 & 0.0079 & 0.0120 & 0.0851 & 0.1060 & 0.0037 & 0.0047 & 0.0546 & 0.0513 \\
\hline \multirow[t]{2}{*}{ GTA } & 0.0000 & $0.0001 *$ & 0.0003 & $0.0011 *$ & 0.0000 & 0.0001 & -0.0005 & $0.0005 * *$ & $0.0030^{* * *}$ & $0.0033 * *$ & $0.0319 *$ & $0.0449 * *$ \\
\hline & 0.0000 & 0.0000 & 0.0002 & 0.0002 & 0.0001 & 0.0000 & 0.0009 & 0.0002 & 0.0017 & 0.0015 & 0.0189 & 0.0176 \\
\hline \multirow[t]{2}{*}{ Intercept factor } & -0.0721 & -0.0983 & -0.5634 & -0.3071 & -0.1113 & -0.1374 & -1.0079 & -0.8094 & -0.0152 & 0.0004 & 0.1744 & 0.7439 \\
\hline & 0.0135 & 0.0425 & 0.2047 & 0.5489 & 0.0176 & 0.0324 & 0.1891 & 0.2912 & 0.0162 & 0.0440 & 0.4497 & 1.1692 \\
\hline Observation & 234 & 234 & 234 & 234 & 108 & 108 & 108 & 108 & 126 & 126 & 126 & 126 \\
\hline Group & 26 & 26 & 26 & 26 & 13 & 13 & 13 & 13 & 14 & 14 & 14 & 14 \\
\hline R2 & 0.3884 & 0.3276 & 0.2776 & 0.2342 & 0.6666 & 0.5165 & 0.5740 & 0.4724 & 0.3731 & 0.3359 & 0.1707 & 0.1031 \\
\hline
\end{tabular}

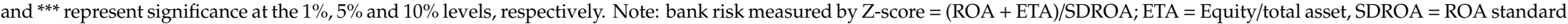
deviation. Independent variables including: net interest income/total income ratio (INT); revenue diversification $(\mathrm{HHI})$ measured by: HHI $=(\mathrm{NON} / \mathrm{NETOP})^{2}+(\mathrm{NET} / \mathrm{NETOP})^{2}$ $\mathrm{NETOP}=\mathrm{NON}+\mathrm{NET}$; NON represents non-interest income, NET represents net interest income. Natural logarithm of total assets (SIZE); loan to total asset ratio (LTA); liquidity ratio = loan outstanding balance/customer deposits (LIQ); equity to total asset ratio (ETA); non-performing loan ratio (NPL); asset growth (GTA). Research data is extracted from audited financial statements in the period 2010-2018, published publicly on the electronic portal of banks and publicly announced at the State Securities Commission of Vietnam. 
Table 9. GMM model—-the impact of revenue diversification on bank risk.

\begin{tabular}{ccccccc}
\hline \multirow{2}{*}{ Variable } & \multicolumn{7}{c}{ Z-Score } \\
\cline { 2 - 7 } & \multicolumn{2}{c}{ Banking System (26) } & \multicolumn{2}{c}{ Listed Bank (12) } & \multicolumn{2}{c}{ Unlisted Banks (14) } \\
\cline { 2 - 6 } & Pooled & Fixed Effect & Pooled & Fixed Effect & Pooled & Fixed Effect \\
\hline HHI & -16.9592 & -73.4480 & -4.0018 & $12.7742 * *$ & -60.2815 & $-120.0412^{* * * *}$ \\
& 73.7673 & 89.7649 & 12.3356 & 5.1253 & 165.1179 & 69.0823 \\
SIZE & 2.0199 & -44.6604 & 12.8728 & $-8.3746^{* *}$ & 49.0409 & $-113.4627^{*}$ \\
& 13.7446 & 34.0561 & 4.8588 & 3.0237 & 34.7700 & 24.3848 \\
LTA & -12.3307 & -7.7556 & -21.3642 & 10.1551 & 0.6757 & -12.2934 \\
& 42.9020 & 15.1637 & 14.7637 & 5.8711 & 79.7648 & 39.6514 \\
LIQ & 7.4200 & 22.6653 & 10.5988 & $7.5995 * * *$ & 1.2986 & $30.7564 *$ \\
& 20.7262 & 16.6958 & 8.3724 & 4.1961 & 35.5776 & 15.0461 \\
ETA & -158.2371 & $146.6115 * *$ & 41.7001 & $161.9017 * *$ & -1.2293 & -66.1437 \\
& 129.8217 & 73.8420 & 53.7398 & 55.9156 & 335.9920 & 132.4654 \\
NPL & 131.4755 & 83.9041 & 112.3704 & $79.8889 * *$ & -249.7761 & -35.9672 \\
& 187.9586 & 109.4308 & 80.4284 & 32.0927 & 508.0504 & 176.3655 \\
INT & -64.5546 & 108.6839 & 32.9859 & -5.0104 & -107.0849 & 172.7163 \\
& 80.3877 & 106.9252 & 12.6504 & 3.4738 & 146.3749 & $54.0877 *$ \\
GTA & -0.1333 & -0.1017 & -0.1624 & 0.0075 & 51.7277 & -8.2381 \\
& 0.1526 & 0.1010 & 0.0588 & 0.0122 & 31.9143 & 10.4810 \\
Intercept & 101.0566 & 333.9465 & -108.9888 & 60.6610 & -200.9881 & 876.6272 \\
factor & 145.9379 & 244.6197 & 38.3586 & 21.5519 & 324.0319 & 202.5602 \\
Observation & 234 & 234 & 108 & 234 & 126 & 126 \\
Group & 26 & 26 & 12 & 12 & 14 & 14 \\
R2 & 0.0285 & 0.2843 & 0.1549 & 0.2363 & 0.1214 & 0.0673
\end{tabular}

$*{ }^{* *}$ and ${ }^{* * *}$ represent significance at the $1 \%, 5 \%$ and $10 \%$ levels, respectively. Note: bank risk measured by Z-score $=($ ROA + ETA $) / S D R O A ; E T A=$ Equity/total asset, SDROA $=$ ROA standard deviation. Independent variables including: net interest income/total income ratio (INT); Revenue diversification (HHI) measured by: $\mathrm{HHI}=(\mathrm{NON} / \mathrm{NETOP})^{2}+(\mathrm{NET} / \mathrm{NETOP})^{2} . \mathrm{NETOP}=\mathrm{NON}+\mathrm{NET} ; \mathrm{NON}$ represents non-interest income, NET represents net interest income. Natural logarithm of total assets (SIZE); loan to total asset ratio (LTA); equity to total asset ratio (ETA); non-performing loan/loan outstanding balance ratio (NPL); asset growth (GTA); liquidity ratio = loan outstanding balance/customer deposits (LIQ). Research data is extracted from audited financial statements in the period 2010-2018, published publicly on the electronic portal of banks and publicly announced at the State Securities Commission of Vietnam.

Table 10. GMM system-Check Robustness of regression.

\begin{tabular}{cccccccccc}
\hline \multirow{2}{*}{ Variable } & \multicolumn{3}{c}{ Banking System (26) } & \multicolumn{3}{c}{ Listed Bank (12) } & \multicolumn{3}{c}{ Unlisted Bank (14) } \\
\cline { 2 - 10 } & ROA & ROE & Z & ROA & ROE & Z & ROA & ROE & Z \\
\hline HHI & $0.0278^{* * *}$ & 0.0538 & 12.7007 & $0.0810^{*}$ & $0.7393^{*}$ & $-10.2105^{*}$ & 0.0253 & $0.2882^{*}$ & $-344.3881^{*}$ \\
& 0.0140 & 0.1940 & 218.0181 & 0.0125 & 0.7220 & 129.8393 & 0.0460 & 0.3814 & 298.8000 \\
SIZE & $0.0125^{*}$ & $0.1111^{*}$ & 4.2403 & 0.0177 & $0.3412^{*}$ & 2.2228 & 0.0035 & 0.0514 & 135.0938 \\
& 0.0039 & 0.0316 & 11.6422 & 0.0206 & 0.1059 & 16.5757 & 0.0118 & 0.1677 & 130.8438 \\
LTA & -0.0025 & $-0.0765^{* * *}$ & -46.4334 & -0.0259 & $-0.5018^{* *}$ & -28.9225 & 0.0053 & 0.0925 & -127.5582 \\
& 0.0055 & 0.0455 & 37.3457 & 0.0216 & 0.1875 & 38.5953 & 0.0457 & 0.1535 & 95.4969 \\
LIQ & $0.0085^{*}$ & $0.1219^{*}$ & -8.7072 & -0.0019 & -0.0621 & -8.2921 & 0.0100 & 0.0990 & -45.9132 \\
& 0.0023 & 0.0424 & 13.1264 & 0.0223 & 0.1128 & 28.7639 & 0.0143 & 0.0985 & 55.7641 \\
ETA & 0.1338 & $0.4357^{* * *}$ & -201.2829 & 0.2243 & 0.2943 & 176.1328 & 0.0695 & 0.4077 & 462.6792 \\
& 0.0330 & 0.2208 & 288.0752 & 0.1317 & 1.5209 & 157.9478 & 0.1051 & 0.8222 & 523.0208 \\
NPL & 0.0320 & 0.4733 & 344.0908 & -0.0987 & 2.7899 & -126.4210 & 0.0947 & 0.5805 & $890.71044^{*}$ \\
& 0.0552 & 0.6523 & 385.1840 & 0.3723 & 2.4728 & 309.3013 & 0.0832 & 0.9339 & 564.6832 \\
INT & $-0.0194 *$ & 0.0054 & -48.1336 & $-0.1024 * *$ & -0.5525 & -0.8150 & -0.0150 & -0.1670 & 405.9794 \\
& 0.0155 & 0.1725 & 280.0172 & 0.0407 & 0.7624 & 162.4012 & 0.0396 & 0.2945 & 359.3684 \\
GTA & 0.0005 & 0.0129 & -1.7425 & 0.0023 & -0.0030 & $7.3651 * *$ & 0.0040 & 0.0771 & 31.9446 \\
& 0.0019 & 0.0162 & 4.3208 & 0.0021 & 0.0277 & 2.6692 & 0.0094 & 0.0581 & 39.7768 \\
Intercept & -0.1176 & -0.9705 & 72.6049 & -0.1157 & -2.5399 & 18.0472 & -0.0498 & -0.6264 & -1064.648 \\
factor & 0.0340 & 0.2637 & 169.2970 & 0.1679 & 0.7531 & 136.3234 & 0.1038 & 1.3944 & 1049.401 \\
\hline Observation & 234 & 234 & 234 & 108 & 108 & 108 & 126 & 126 & 126 \\
\hline Group & 26 & 26 & 26 & 12 & 12 & 12 & 14 & 14 & 14 \\
\hline F-statistic & 5.25 & 3.54 & 1.10 & 1.12 & 2.94 & 3.97 & 1.24 & 2.26 & 11.02 \\
\hline AR (2) & 0.01 & 0.14 & 0.50 & -0.28 & 0.25 & -0.48 & -1.09 & 0.16 & -0.76 \\
\hline Hansen test & 21.18 & 20.86 & 11.68 & 1.50 & 1.95 & 3.3 & 7.44 & 8.25 & 1.01 \\
\hline and
\end{tabular}

$* *^{* *}$ and ${ }^{* * *}$ represent significance at the $1 \%, 5 \%$ and $10 \%$ levels, respectively. Note: bank risk measured by $\mathrm{Z}$-score $=(\mathrm{ROA}+\mathrm{ETA}) / \mathrm{SDROA} ; \mathrm{ETA}=$ Equity/asset, $\mathrm{SDROA}=\mathrm{ROA}$ standard deviation. Independent variables including: net interest income/total income ratio (INT); Revenue diversification (HHI) measured by: $\mathrm{HHI}=(\mathrm{NON} / \mathrm{NETOP})^{2}+(\mathrm{NET} / \mathrm{NETOP})^{2} . \mathrm{NETOP}=\mathrm{NON}+\mathrm{NET} ; \mathrm{NON}$ represents non-interest income, NET represents net interest income. Natural logarithm of total assets (SIZE); loan to total asset ratio (LTA); equity to total asset ratio (ETA); non-performing loan/loan outstanding balance ratio (NPL); asset growth (GTA); liquidity ratio = loan outstanding balance/customer deposits (LIQ). Research data is extracted from audited financial statements in the period 2010-2018, published publicly on the electronic portal of banks and publicly announced at the State Securities Commission of Vietnam. 


\section{Conclusions}

The bank is the capital circulatory system of the economy; thus, assessing the financial condition of commercial banks is an important step in the risk management process to forecast the economic situation. Credit risk is one of the causes of the weaknesses of the commercial banking system, leading to restructuring in recent years. The process of restructuring the commercial banking system is still going on; the question raised is: which management method should be used to assess and forecast bank revenue and bankruptcy risks? Determining how the revenue diversification affects performance and safety, stabilizing the banking system to help banks time to provide interventions as well as appropriate solutions. In the world, there have been many researches work on this issue and have given meaningful experimental results, approaching in many different research aspects, the impact results may be similar or different depending on bank characteristics, geographical location and national political economy. However, in Vietnam, most of the studies have not yet produced quantitative research models and have rarely been published in journals or on other financial information channels. Therefore, the analysis of the impact of revenue diversification on performance and bank risk is an extremely urgent issue. The research model is based on the grouped factors of revenue diversification (INT, HHI). In particular, revenue diversification is measured by indexes of Mercieca et al. (2007); $\mathrm{HHI}=(\mathrm{NON} / \mathrm{NETOP})^{2}+(\mathrm{NET} / \mathrm{NETOP})^{2}$. Performance measured by financial performance (ROA, $\mathrm{ROE})$, the bank risk using the index Z-score $=(\mathrm{ROA}+\mathrm{ETA}) / \mathrm{SDROA}$ to measure as the study of Roy (1952); Boyd and Runkle (1993); Chiorazzo et al. (2008); Lepetit and Strobel (2015); Lee et al. (2014). Using the quantitative analysis method with tests to evaluate the fixed effects model (FEM) and the random effects model (REM) to extract research result. The results of GMM system research have verified the negative impact of revenue diversification on bank performance. However, the revenue diversification at listed banks is different when the impact reduces risks for the banks. Interest income is still the motivation for the development of banks; the more this income increases, the more profits and systemic risks increase. The benefit of revenue diversification is offset by the increase in non-interest activity; however, it also adjusts the risk of banks (Demirgüç-Kunt and Huizinga 2010; Li and Zhang 2013). This shows the weakness and lack of experience in the banking system in building a reasonable profit transformation model. The pressure to implement Basel II forces banks to shift in business operations, restructure credit activities, and restructure revenue. In fact, banks which cannot promote credit will turn to promote the development of services to increase revenue; however, it is difficult to expect a strong increase in a short time. Some large-scale banks that lead the retail sector show signs of declining revenue from services. Growth, as well as the contribution from service activities, is not commensurate with potentials; although there are many positive points, they are not enough to cover risks from net interest income activities. Therefore, the Vietnamese commercial banking system needs to improve and enhance the non-credit service quality, especially e-banking services, to meet the trend of competition in banking digitization and the trend of consumer consumption. The better the banking liquidity is, the higher the profitability of the credit institutions. However, there have been positive solutions in ensuring liquidity and safety such as adjusting interest rates, diversifying capital mobilization products, flexible in deposit terms and improving service quality have helped the bank to prevent risks and ensure the safety and stability of the system.

Funding: This research received no external funding.

Conflicts of Interest: The author declares no conflict of interest.

\section{References}

Acharya, Viral V., Iftekhar Hasan, and Anthony Saunders. 2006. Should banks be diversified? Evidence from individual bank loan portfolios. The Journal of Business 79: 1355-412. [CrossRef]

Aggarwal, Raj, and Kevin T. Jacques. 2001. The impact of FDICIA and prompt corrective action on bank capital and risk: Estimates using a simultaneous equations model. Journal of Banking E Finance 25: 1139-60. 
Agoraki, Maria-Eleni K., Manthos D. Delis, and Fotios Pasiouras. 2011. Regulations, competition and bank risk-taking in transition countries. Journal of Financial Stability 7: 38-48. [CrossRef]

Aigner, Dennis, C. A. Knox Lovell, and Peter Schmidt. 1977. Formulation and estimation of stochastic frontier production function models. Journal of Econometrics 6: 21-37. [CrossRef]

Arellano, Manuel, and Olympia Bover. 1995. Another look the instrumental variable estimation of error-components models. Journal of Econometrics 68: 29-51. [CrossRef]

Baele, Lieven, Olivier De Jonghe, and Rudi Vander Vennet. 2007. Does the stock market value bank diversification? Journal of Banking \& Finance 31: 1999-2023. [CrossRef]

Beck, Thorsten, Olivier De Jonghe, and Glenn Schepens. 2013. Bank competition and stability: Cross-country heterogeneity. Journal of Financial Intermediation 22: 218-44. [CrossRef]

Berger, Allen N. 1995. The relationship between capital and earnings in banking. Journal of Money, Credit and Banking 27: 432-56. [CrossRef]

Berger, Allen N., and Loretta J. Mester. 1997. Efficiency and Productivity Change in the US Commercial Banking Industry: A Comparison of the 1980s and 1990s. Philadelphia: Federal Reserve Bank of Philadelphia.

Berger, Allen N., Iftekhar Hasan, and Mingming Zhou. 2010. The effects of focus versus diversification on bank performance: Evidence from Chinese banks. Journal of Banking E Finance 34: 1417-35.

Bikker, Jacob, and Jaap W. B. Bos. 2008. Bank Performance: A Theoretical and Empirical Framework for the Analysis of Profitability, Competition and Efficiency. London: Routledge.

Bikker, Jacob A., and Paul A. J. Metzemakers. 2005. Bank provisioning behaviour and procyclicality. Journal of International Financial Markets, Institutions and Money 15: 141-57. [CrossRef]

Blundell, Richard, and Stephen Bond. 2000. GMM estimation with persistent panel data: an application to production functions. Econometric Reviews 19: 321-40. [CrossRef]

Boot, Arnoud W. A., and Anjolein Schmeits. 2000. Market discipline and incentive problems in conglomerate firms with applications to banking. Journal of Financial Intermediation 9: 240-73. [CrossRef]

Bourke, Philip. 1989. Concentration and other determinants of bank profitability in Europe, North America and Australia. Journal of Banking E Finance 13: 65-79.

Boyd, John H., and David E. Runkle. 1993. Size and performance of banking firms: Testing the predictions of theory. Journal of Monetary Economics 31: 47-67. [CrossRef]

Brighi, Paola, Valeria Venturelli, and Centro Studi Banca e Finanza. 2014. The effect of revenue and geographic diversification on bank performance. Paper Presented at the European Financial Management Association 2014 Annual Meetings, Lugano, Switzerland, June 25-28.

Chiorazzo, Vincenzo, Carlo Milani, and Francesca Salvini. 2008. Income diversification and bank performance: Evidence from Italian banks. Journal of Financial Services Research 33: 181-203. [CrossRef]

Curi, Claudia, Ana Lozano-Vivas, and Valentin Zelenyuk. 2015. Foreign bank diversification and efficiency prior to and during the financial crisis: Does one business model fit all? Journal of Banking E Finance 61: S22-S35.

De Andres, Pablo, and Eleuterio Vallelado. 2008. Corporate governance in banking: The role of the board of directors. Journal of Banking \& Finance 32: 2570-80.

De Jonghe, Olivier. 2010. Back to the basics in banking? A micro-analysis of banking system stability. Journal of Financial Intermediation 19: 387-417. [CrossRef]

Delis, Manthos D., Philip Molyneux, and Fotios Pasiouras. 2011. Regulations and productivity growth in banking: Evidence from transition economies. Journal of Money, Credit and Banking 43: 735-64. [CrossRef]

Delpachitra, Sarath, and Laurence Lester. 2013. Non-Interest Income: Are Australian Banks Moving Away from their Traditional Businesses? Economic Papers: A Journal of Applied Economics and Policy 32: 190-99. [CrossRef]

De-Min, Wu. 1973. Alternative tests of independence between stochastic regressors and disturbances. Econometrica (pre-1986) 41: 733.

Demirgüç-Kunt, Ash, and Harry Huizinga. 1999. Determinants of commercial bank interest margins and profitability: Some international evidence. The World Bank Economic Review 13: 379-408. [CrossRef]

Demirgüç-Kunt, Asli, and Harry Huizinga. 2010. Bank activity and funding strategies: The impact on risk and returns. Journal of Financial Economics 98: 626-50. [CrossRef]

Demsetz, Rebecca S., and Philip E. Strahan. 1997. Diversification, size, and risk at bank holding companies. Journal of Money, Credit, and Banking 29: 300-13. [CrossRef]

DeYoung, Robert, and Tara Rice. 2004. Noninterest income and financial performance at US commercial banks. Financial Review 39: 101-27. [CrossRef] 
DeYoung, Robert, and Karin P. Roland. 2001. Product mix and earnings volatility at commercial banks: Evidence from a degree of total leverage model. Journal of Financial Intermediation 10: 54-84. [CrossRef]

DeYoung, Robert, and Gökhan Torna. 2013. Nontraditional banking activities and bank failures during the financial crisis. Journal of Financial Intermediation 22: 397-421. [CrossRef]

Elsas, Ralf, Andreas Hackethal, and Markus Holzhäuser. 2010. The anatomy of bank diversification. Journal of Banking E Finance 34: 1274-87.

Fiordelisi, Franco, David Marques-Ibanez, and Phil Molyneux. 2011. Efficiency and risk in European banking. Journal of Banking E Finance 35: 1315-26.

Gamra, Saoussen Ben, and Dominique Plihon. 2011. Revenue diversification in emerging market banks: implications for financial performance. arXiv, arXiv:1107.0170.

Geambasu, Cristina, Robert Sova, Iulia Jianu, and Liviu Geambasu. 2013. Risk measurement in post-modern portfolio theory: differences from modern portfolio theory. Economic Computation \& Economic Cybernetics Studies \& Research 47: 113-32.

Goddard, John, Phil Molyneux, and John OS Wilson. 2004. Dynamics of growth and profitability in banking. Journal of Money, Credit and Banking 36: 1069-90. [CrossRef]

González-Hermosillo, Ms Brenda. 1999. Determinants of ex-Ante Banking System Distress: A Macro-Micro Empirical Exploration of Some Recent Episodes. Washington: International Monetary Fund.

Halling, Michael, and Evelyn Hayden. 2006. Bank Failure Prediction: A Two-Step Survival Time Approach. Available online: https://ssrn.com/abstract=904255 (accessed on 25 May 2019).

Hassan, M. Kabir, and Abdel-Hameed M. Bashir. 2003. Determinants of Islamic banking profitability. Paper Presented at the 10th ERF Annual Conference, Morocco, Kuwait City, Kuwait, March 10-12.

Hausman, Jerry A. 1978. Specification tests in econometrics. Econometrica: Journal of the Econometric Society 46: 1251-71. [CrossRef]

Hsieh, Meng-Fen, Pei-Fen Chen, Chien-Chiang Lee, and Shih-Jui Yang. 2013. How does diversification impact bank stability? The role of globalization, regulations, and governance environments. Asia-Pacific Journal of Financial Studies 42: 813-44. [CrossRef]

Hughes, Joseph P., and Loretta J. Mester. 1998. Bank capitalization and cost: Evidence of scale economies in risk management and signaling. Review of Economics and Statistics 80: 314-25. [CrossRef]

Jianu, Ionel, Iulia Jianu, and Carmen Țurlea. 2017. Measuring the company's real performance by physical capital maintenance. Economic Computation and Economic Cybernetics Studies and Research 51: 21.

Kick, Thorsten Beck Heiko Hesse Thomas, and Natalja von Westernhagen. 2009. Bank Ownership and Stability: Evidence from Germany. Boston: VOX CEPRs Policy Portal.

Köhler, Matthias. 2015. Which banks are more risky? The impact of business models on bank stability. Journal of Financial Stability 16: 195-212. [CrossRef]

Laeven, Luc, and Ross Levine. 2007. Is there a diversification discount in financial conglomerates? Journal of Financial Economics 85: 331-67. [CrossRef]

Laeven, Luc, and Ross Levine. 2009. Bank governance, regulation and risk taking. Journal of Financial Economics 93: 259-75. [CrossRef]

Laeven, Luc, and Giovanni Majnoni. 2003. Loan loss provisioning and economic slowdowns: too much, too late? Journal of Financial Intermediation 12: 178-97. [CrossRef]

Lee, Chien-Chiang, Shih-Jui Yang, and Chi-Hung Chang. 2014. Non-interest income, profitability, and risk in banking industry: A cross-country analysis. The North American Journal of Economics and Finance 27: 48-67. [CrossRef]

Lehar, Alfred. 2005. Measuring systemic risk: A risk management approach. Journal of Banking $\mathcal{E}$ Finance 29: 2577-603.

Lepetit, Laetitia, and Frank Strobel. 2015. Bank insolvency risk and Z-score measures: A refinement. Finance Research Letters 13: 214-24. [CrossRef]

Lepetit, Laetitia, Emmanuelle Nys, Philippe Rous, and Amine Tarazi. 2008. Bank income structure and risk: An empirical analysis of European banks. Journal of Banking $\mathcal{E}$ Finance 32: 1452-67.

$\mathrm{Li}$, Li, and Yu Zhang. 2013. Are there diversification benefits of increasing noninterest income in the Chinese banking industry? Journal of Empirical Finance 24: 151-65. [CrossRef]

Liang, Qi, Pisun Xu, and Pornsit Jiraporn. 2013. Board characteristics and Chinese bank performance. Journal of Banking E Finance 37: 2953-68. 
McAllister, Patrick H., and Douglas McManus. 1993. Resolving the scale efficiency puzzle in banking. Journal of Banking E Finance 17: 389-405.

Mercieca, Steve, Klaus Schaeck, and Simon Wolfe. 2007. Small European banks: Benefits from diversification? Journal of Banking E Finance 31: 1975-98.

Meslier, Céline, Ruth Tacneng, and Amine Tarazi. 2014. Is bank income diversification beneficial? Evidence from an emerging economy. Journal of International Financial Markets, Institutions and Money 31: 97-126. [CrossRef]

Norden, Lars, and Martin Weber. 2010. Funding modes of German banks: structural changes and their implications. Journal of Financial Services Research 38: 69-93. [CrossRef]

Poghosyan, Tigran, and Martin Čihak. 2011. Determinants of bank distress in Europe: Evidence from a new data set. Journal of Financial Services Research 40: 163-84. [CrossRef]

Porter, Robert L., and Wan-Jiun Paul Chiou. 2013. How has capital affected bank risk since implementation of the Basel accords. Banks and Bank System 1: 1-52.

Rossi, Stefania P. S., Markus S Schwaiger, and Gerhard Winkler. 2009. How loan portfolio diversification affects risk, efficiency and capitalization: A managerial behavior model for Austrian banks. Journal of Banking $\mathcal{E}$ Finance 33: 2218-26.

Roy, Andrew Donald. 1952. Safety first and the holding of assets. Econometrica: Journal of the Econometric Society 20: 431-49. [CrossRef]

Sanya, Sarah, and Simon Wolfe. 2011. Can banks in emerging economies benefit from revenue diversification? Journal of Financial Services Research 40: 79-101. [CrossRef]

Schultz, Emma L., David T. Tan, and Kathleen D. Walsh. 2010. Endogeneity and the corporate governance-performance relation. Australian Journal of Management 35: 145-63. [CrossRef]

Stiroh, Kevin J. 2004a. Diversification in banking: Is noninterest income the answer? Journal of Money, Credit, and Banking 36: 853-82. [CrossRef]

Stiroh, Kevin J. 2004b. Do community banks benefit from diversification? Journal of Financial Services Research 25: 135-60. [CrossRef]

Stiroh, Kevin J., and Adrienne Rumble. 2006. The dark side of diversification: The case of US financial holding companies. Journal of Banking E Finance 30: 2131-61.

Vallascas, Francesco, and Kevin Keasey. 2012. Bank resilience to systemic shocks and the stability of banking systems: Small is beautiful. Journal of International Money and Finance 31: 1745-76. [CrossRef]

Vennet, Rudi Vander. 2002. Cost and profit efficiency of financial conglomerates and universal banks in Europe. Journal of Money, Credit and Banking 34: 254-82. [CrossRef]

Williams, Barry, and Laurie Prather. 2010. Bank risk and return: the impact of bank non-interest income. International Journal of Managerial Finance 6: 220-44. [CrossRef]

World Bank. 2018. Management's Discussion \& Analysis and Financial Statements (Fiscal 2018). Available online: http://documents.worldbank.org/curated/en/473291538159094998/Annual-Report-2018Managements-Discussion-and-Analysis-and-Financial-Statements-Fiscal-2018 (accessed on 25 May 2019).

(C) 2019 by the author. Licensee MDPI, Basel, Switzerland. This article is an open access article distributed under the terms and conditions of the Creative Commons Attribution (CC BY) license (http://creativecommons.org/licenses/by/4.0/). 